\begin{tabular}{|c|c|c|c|}
\hline$p \mathbf{H}$ & Calculated & Observed & Deviation \\
\hline 0.188 & $+0 \cdot 369 \mathrm{v}$ & $+0 \cdot 369 \mathrm{v}$ & 0.000 \\
\hline $\begin{array}{l}1 \cdot 005 \\
1 \cdot 390\end{array}$ & $\begin{array}{r}0.320 \\
0.297\end{array}$ & $\begin{array}{l}0.322 \\
0.299\end{array}$ & $\begin{array}{l}-0.002 \\
-0.002\end{array}$ \\
\hline $\begin{array}{l}1.390 \\
2.454\end{array}$ & $0 \cdot 232$ & 0.231 & +0.001 \\
\hline $3 \cdot 392$ & $0 \cdot 176$ & $0 \cdot 176$ & $0 \cdot 000$ \\
\hline $4 \cdot 477$ & $0 \cdot 111$ & $0 \cdot 111$ & $0 \cdot 000$ \\
\hline $5 \cdot 570$ & 0.045 & 0.045 & $0 \cdot 000$ \\
\hline $6 \cdot 119$ & $\begin{array}{l}+0.010 \\
+0.0\end{array}$ & +0.012 & +0.002 \\
\hline 6.583 & -0.021 & $-0 \cdot 016$ & +0.005 \\
\hline 6.867 & 0.042 & 0.032 & -0.010 \\
\hline $7 \cdot 431$ & 0.085 & $0 \cdot 081$ & -0.004 \\
\hline $7 \cdot 880$ & $0 \cdot 123$ & $0 \cdot 122$ & -0.001 \\
\hline $8 \cdot 338$ & $0 \cdot 163$ & 0.163 & 0.000 \\
\hline $9 \cdot 186$ & $0 \cdot 231$ & 0.231 & $0 \cdot 000$ \\
\hline $9 \cdot 547$ & 0.256 & 0.256 & $0 \cdot 000$ \\
\hline 10.053 & 0.284 & 0.285 & +0.001 \\
\hline $10 \cdot 605$ & 0.307 & $0 \cdot 308$ & +0.001 \\
\hline $11 \cdot 454$ & $0 \cdot 335$ & $0 \cdot 336$ & +0.001 \\
\hline $11 \cdot 743$ & $0 \cdot 344$ & 0.345 & +0.001 \\
\hline $12 \cdot 228$ & $-0 \cdot 359$ & $-0 \cdot 360$ & $+0 \cdot 001$ \\
\hline
\end{tabular}

acid or sulphuric acid, a blue-green compound, presumably a meriquinone, is formed by the reduction of resorufin with titanous salts, or by oxidation of dihydroresorufin with quinone or potassium dichromate. While the reduction method shows that a meriquinone having an oxidant : reductant ratio of $1: 1$ occurs, the oxidation method, curiously, shows a $3: 2$ ratio.

If a solution of resazurin be acidified to $4 \cdot 76 \mathrm{~N}$ with hydrochloric acid, and potassium iodide be added to a final concentration of $0.06 \mathrm{~N}$, a spontaneous reduction of the resazurin proceeds not only to resorufin, but also to a further half reduction of the resorufin so formed to the meriquinone stage, with the release of the equivalent amount of iodine, which may be extracted with carbon tetrachloride and determined by an iodate titration. On the other hand, if the resazurin be acidified to $3 N$ with sulphuric acid or about $1.2 \mathrm{~N}$ with hydrochloric acid, and potassium iodide added to $0.06 \mathrm{~N}$, only the complete reduction of resazurin, without further reduction of the resorufin so formed, occurs. This difference depends upon the low solubility of resorufin in the medium, and upon the observation that at these high acidities the potential of an iodine-potassium iodide mixture at an inert electrode decreases with increasing acidity, which is contrary to experience with other systems.

Commercial resazurin contains variable amounts of resorufin. These latter findings have led to the development of a method for estimating the amount of resazurin in a sample together with any resorufin present as an 'impurity'.

If $A$ is the iodine equivalent of the first procedure, and $B$ that of the second, then, if $R Z=$ resazurin, $R F=$ resorufin :

$$
\begin{aligned}
A & =2 R Z+[R Z \text { (as 'formed' } R F)+R F \text { (as 'impurity') }] \\
& =3 R Z+R F \\
B & =2 R Z, \text { or } R Z=\frac{B}{2} \\
\therefore A & =\frac{3 B+2 R F}{2}, \\
\text { and } R F & =\frac{2 A-3 B .}{2}
\end{aligned}
$$

These equations have been verified by electrometric investigations carried out in conjunction with iodine ostimations.

I am indebted to the Agricultural Research Council for a grant in aid of this work.

\footnotetext{
${ }^{1}$ Weselsky, Berichte, 4, 32, 613 (1871).
}

'Pesch, K. L., and Simmert, U., Milchw. Forsch., 8, 551 (1929)

s Baker, W., et al., Biochem. J., 36, 1/2, i (1942).

' Davis, J. G., Food Manufacture, 17, 308, 344 (1942).

.5 Clark, W. M., U.S. Pub. Health Rep. (Reprint No. 826).

\section{INDUSTRY AND UNIVERSITY EDUCATION}

$\mathrm{T}$ HE proceedings of the Conference of Industrial Representatives on "Industry and University Education", convened by the Vacation Work Committee of the Imperial College of Science and Technology Union on December 15, have now been published. At the first session, on "Post-war Technical Requirements in Industry", Dr. P. Dunsheath, in a paper on "Industry's Requirements in Personality", suggested that university education tends to lay too much emphasis on the working of things and to give insufficient attention to human relationships and the working of the mind. University graduates are of much greater value to industry when, in addition to their equipment of mathematical and scientific data, they possess some knowledge of humanity with its intricate and sometimes contradictory relations. Urging that the universities should concern themselves with developing the characteristics making for leadership, Dr. Dunsheath emphasized the importance of a sense of proportion and the ability to get ideas understood by others. He believes that more attention should be given to the classification of students according to their real aptitude for research, for design, for production or for teaching: good brains are required in design and production as well as in research, and above all in teaching. All administrative posts in scientific industry should be filled, he thinks, by those with scientific and technical knowledge of the industry.

Mr. E. R. Davies, director of research, Messrs. Kodak, Ltd., pointing out that the problems of the industrial research worker always tend to lead him back to problems in pure or applied science which are not peculiar to his industry but of much wider interest, deprecated further specialization during the undergraduate years. More emphasis should be placed on postgraduate work, but the men required should be scientists first and technologists second. $\mathrm{He}$ thinks that technologists in the production and distribution sides would be drawn largely from the technical colleges. Although he would welcome the establishment of a university chair in photography, he would prefer to see postgraduate training continued in pure and applied science as it is at present. Its main aim should be to train a man in research methods, but he would like to see some broadening of the basis of scientific training at the graduate stage. There should be the closest possible contact between the universities and industry.

In the discussion, Lord Eustace Percy suggested that industry should find more men within its own ranks who are worthy of a university education and could profit by it. Dr. G. M. Dyson referred to the need for thoroughly re-organizing the technical colleges, adequately endowing and equipping them and providing them with sufficient men to cope with teaching and to prosecute research as well. Dr. J. A. C. Williams put in a plea for including the philosophy and psychology of engineering in the university engineering course, and for increased use of the technical colleges for refresher purposes.

The second session of the Conference, which considered "Post-war Requirements in Scientific Education", was opened by Prof. L. Bairstow, who pointed out that scientific education cannot be considered adequately as a separate subject apart from the rest of life, and referred to the economic difficulties 
attending any extension of a student's career, especially for the majority whose work is less absorbing than research and where compensations are necessary. Specialization, or differentiation, should not come before the third year, and even then should not involve a student being committed to one field for the rest of his life. He believes that we need more training in administration for a limited number of people, who would in due course take their place with those who have studied life from a different aspect. Then we should retain, and possibly extend, a completely free atmosphere for those students who take naturally to research. We also need a better administrative attitude to research, and also technical high-schools and extended facilities in the ordinary technical schools.

Prof. H. V. A. Briscoe confined himself to the question of producing men destined for teaching positions in pure and applied science and in the industries using applied science. He stressed the importance in recruitment of selection and of widening the field of choice; we must look critically and constructively at this question of extended recruitment and make a scientific career attract more of the really good men who at present go into other fields. Then he stressed the importance of excellence in the teaching staff with reference to imparting selected principles and facts in science so as to inculcate and develop intelloctual integrity and to display the cultural aspects of science, as well as to the provision of opportunities for special development. Curricula are overloaded, and we must remember that the task is education, not teaching. Lastly, there is the question of assessment and guidance in the valuation of the graduate, so that he does what is best in his own interest and in the interests of the community. Here full co-operation of the employer is essential. With regard to the desirability of having first-class men for production, he believes that the choice between research and production should be left open and that we should aim at turning out keen, properly equipped scientific workers, whose careers would be determined by their aptitudes and opportunities.

Dr. R. V. Southwell, stressing the importance of a real partnership with industry, suggested that we may find that the best arrangement is not one in which three years at a university are followed by two years in industry, but one in which the last of the five years sees a man returning to his university. A man who enters industry should not have finished with his university, and we might well keep a more open mind on the order in which the years are spent between industry and the university.

Mr. J. W. Sawtell emphasized the importance of good management; he thinks that we should impress on the universities the need for men with a scientific education who can manage and handle other poople, and appreciate the importance and dignity of management as a profession. Mr. L. P. Combes pointed out that regard must be had to the question of national service and its incidence on the age of recruitment. Mr. D. A. Bell thinks that one reason why graduates tend to enter industry only in research departments is that management has not been regarded as a worthy or scientific profession. In written subsequent contributions, Mr. W. S. Flight referred to the economic difficulties of a long period of training and a possible solution through the State bursary scheme, and Mr. M. I. Freeman urged that some training in the principles of industrial administration and organization should be given by the university rather than by industry.

Dr. A. J. F. Welch referred to the importance of vacation work and of having on academic staffs those with first-hand acquaintance with industrial conditions, while Dr. F. M. Potter, urging the value of a sound fundamental knowledge and elementary back. ground of several subsidiary sciences, suggested that students would do well to avoid the tendency to live with men in the same year who are studying the same branch of seience.

\section{MODE OF ACTION OF PENICILLIN}

$\mathbf{N}$ an article on penicillin treatment in Nature $(677$, Nov. 25, 1944) reference was made to the work of Lieut.-Colonel J. W. Bigger (Lancet, 497, Oct. 14, 1944), who concluded that penicillin actually kills Staphylococcus pyogenes. He suggested that it kills them at the time of division and has no effect upon individual cocci which are not dividing. These, therefore, persist in broth cultures, which penicillin frequently fails to sterilize, and are the explanation of that failure. Bigger proposed to give penicillin intermittently, in the hope that these 'persisters' would begin dividing in the intervals of the penicillin doses and so would be killed by the next dose. Bigger refers to the work of C. D. Gardner (Nature, 146, 837 ; 1940), who found that, in weak concentrations of penicillin, cocci swelled to three times their normal size without division, and bacilli showed similar changes.

E. W. Todd (Lancet, 74, Jan. 20, 1945) also refers to this and other work in his report on his experiments on the bacteriolytic action of penicillin. Working with Pneumococcus Types I, II and III and with Streptococcus viridans, hæmolytic streptococci, staphylococci and Clostridium welchii, he found that all the strains of these organisms which he used were lysed by penicillin, but that such organisms as Bact. coli and Pseudomonas pyocyanea, which resist penicillin, were not lysed by it. But penicillin, he concluded, can kill organisms without lysis. When lysis occurs, its rate depends on the actual or potential rate of multiplication of the organisms. Their multiplication, as G. L. Hobby, K. Meyer and E. Chaffee (Proc. Soc. Expt. Biol., N.Y., 50, 281; 1942) also found, is essential for the action of penicillin. "It would appear that bacteriostasis, bactericidal action and bacteriolysis may be different stages of a single process proceeding in that order." The most rapid lysis occurs with organisms at the maximal rate of multiplication. This may be the real reason why penicillin is so effective, that is, because young actively multiplying cultures are more susceptible to bacteriolysis, so that organisms in the phase which enables them most readily to invade the human body are also then most susceptible to lysis.

These conclusions may be compared with those of Prof. L. P. Garrod (Brit. Med. J., 108, Jan 27, 1945), who agrees that penicillin actually kills susceptible bacteria. $\mathrm{He}_{\theta}$ quotes the further opinion of $\mathrm{L}$. A. Rautz and W. M. M. Kirby (J. Immunol., 48, 335 ; $1944)$ that penicillin is actually bactericidal. Garrod gives, however, only qualified support to Bigger's hypothesis that penicillin is bactericidal only to organisms when they are about to divide, which was, he says, also put forward by G. L. Hobby and M. H. Dawson (Proc. Soc. Expt. Biol., N.Y., 56, 178 ; 1944) and by C. P. Miller and A. Z. Foster (ibid., 56, 205). 